\title{
Kierkegaard at the Intersections: The Single Individual and Identity Politics
}

\section{J. Aaron Simmons}

Citation: Simmons, J. Aaron. 2021 Kierkegaard at the Intersections: The Single Individual and Identity Politics. Religions 12: 547. https:// doi.org/10.3390/rel12070547

Academic Editor: Christopher B. Barnett

Received: 7 June 2021

Accepted: 14 July 2021

Published: 19 July 2021

Publisher's Note: MDPI stays neutral with regard to jurisdictional claims in published maps and institutional affiliations.

Copyright: (C) 2021 by the author. Licensee MDPI, Basel, Switzerland. This article is an open access article distributed under the terms and conditions of the Creative Commons Attribution (CC BY) license (https:// creativecommons.org/licenses/by/ $4.0 /)$.
Department of Philosophy, Furman University, Greenville, SC 29613, USA; aaron.simmons@furman.edu

\begin{abstract}
Kierkegaard's authorship is frequently charged with being so radically individualistic that his work is of little use to social theory. However, in this essay, I argue that Kierkegaard's notion of "the single individual" actually offers important critical resources for some aspects of contemporary identity politics. Through a focused consideration of the two notes that form the little essay, "The Individual" (published with Point of View), I suggest that Kierkegaard does not ignore embodied historical existence, as is sometimes claimed, but instead simply rejects the idea that one's moral dignity is determined by, or reducible to, such embodied differentiation. Instead, what we find in Kierkegaard is a rejection of the quantitative judgment of "the crowd" in favor of the qualitative neighbor-love of community. In light of Kierkegaard's claim that it is the specifically religious category of the single individual that makes possible true human equality, I contend that we can develop a Kierkegaardian identity theory consistent with some aspects of the standpoint and intersectionality theory of Patricia Hill Collins and Kimberlé Crenshaw. Although Collins and Crenshaw operate at a structural level and Kierkegaard works at a theological level, they all offer important reminders to each other about the stakes of lives of meaning in light of the embodied task of social justice.
\end{abstract}

Keywords: Kierkegaard; community; Patricia Hill Collins; Kimberlé Crenshaw; politics; social theory; Philosophy of Religion; identity theory

\section{Introduction}

No careful reading of Søren Kierkegaard is likely to yield a sustainable vision for public policy. But in full recognition of the passages in his work that do stress the distance of his thought from political life, and also acknowledging the robust scholarship that has tried to apply his work to political existence, ${ }^{1}$ I think that there has generally been a missed opportunity to see the notion of "the single individual" (hiin Enkelte) as potentially compatible with some aspects of contemporary identity politics. Specifically, a Kierkegaardian (as opposed to Kierkegaard's) identity theory, as it were, would not focus on embodied difference as a matter of losing oneself in a group or social category, what he terms an "alliance," but instead on what it means for God to know us "by name," as single individuals (Kierkegaard 1962, pp. 111-12). For Kierkegaard, our social location does not determine our ethico-religious dignity, but instead forms the context in which we are able to take ourselves up as irreducible to what Kierkegaard repeatedly terms, "the crowd". I will suggest that such a Kierkegaardian account resonates in important ways with standpoint and intersectionality theory that emerges in light of the work of scholars such as Patricia Hill Collins and Kimberlé Crenshaw. Although Collins and Crenshaw will understand individual identity as a structural reality and Kierkegaard will understand it as a religious reality, they are all invested in the idea that, in the name of human equality, selfhood is irreducible to the workings of power that threaten to turn us into anonymous members of some quantitative calculus resulting from an abstract unity: the species, the public, the they, the crowd, etc. 
In the hope of developing this idea in a manageable way, I will turn to what I think is an under-appreciated essay in Kierkegaard's authorship, "The Individual" (Kierkegaard 1962). Therein, he directly identifies the single individual as being oriented toward every human being such that every person is known by God. The very ideas of "humanity" and, specifically, of "human equality" emerge as a result of such religious singularity. In order to provide something of a case study for such a Kierkegaardian identity theory, I will look to the Biblical story of the Samaritan woman (as offered in John 4) in order to argue that an emphasis on the single individual does not necessarily downplay or ignore the specificity of human embodied difference, but instead allows such difference to signify within a deeper notion of "religious" equality.

Importantly, I acknowledge that my general thesis is likely to be controversial to at least some Kierkegaard scholars who, with some warrant, stress the fact that Kierkegaard just is not willing to side with particular matters of social life and public policy. Although he is deeply interested in making Christianity accessible to all people, they might suggest, his interests in this regard sidestep any worries about contemporary concerns such as systemic racism, gender theory, and the queering of social spaces. That said, what follows is not meant to be a final refutation of such interpretive options-which Kierkegaard's texts certainly leave open to some degree. While recognizing that it is a flawed strategy to try to make Kierkegaard speak to all issues that we wish he had addressed (or may have addressed in undeveloped or problematic ways), we should still remain willing to think constructively as Kierkegaardians about where we find ourselves in the world today. That is my attempt in this essay. The Kierkegaardian identity theory I develop here is offered as not only a possible way to read Kierkegaard's work, but a quite plausible way to approach his work as inviting constructive gestures that might require then moving beyond it.

\section{Radical Individualism vs. the Single Individual}

Perhaps second only to the charge of irrationalism associated with "the leap of faith" (a phrase, I should note, that does not appear in Kierkegaard's work), the idea that Søren Kierkegaard is a radical individualist with no deep concern for the material actuality of others is arguably the most common critical misreading of his complicated authorship. Charges on this front range from claims of "acosmism" (Mackey 1962), and "moral nihilism" (Blanshard 1969, 1975), to contentions that Kierkegaard is "inhumane" (Garff 2005), and even "misanthropic" (Adorno 1939, 1989). ${ }^{2}$ Although numerous scholars have defended Kierkegaard against such objections in various ways (see, e.g., Evans 2019; Ferreira 2001; Pattison 2005; Westphal 1991, 2013; Walsh 1999, 2018), ${ }^{3}$ these charges of radical individualism are influential, and persistent, precisely because Kierkegaard frequently deploys rhetoric that can seem to support such readings.

Of particular note is his conception of "the single individual" (hiin Enkelte), which Kierkegaard first introduces in the preface to Two Upbuilding Discourses of 1843 (Kierkegaard 1990a, pp. 1-48). ${ }^{4}$ Reflecting on this first mention of the concept in Point of View, Kierkegaard explicitly claims that the category of the single individual is crucial for understanding the general trajectory of his authorship:

I was conscious of being a religious author and as such was concerned with "the individual" ("the individual" - in contrast to "the public"), a thought in which is contained an entire philosophy of life and of the world.

(Kierkegaard 1962, p. 21)

Marking such a rigid distinction between the single individual and the public, Kierkegaard certainly does not make it easy for readers who would like to find clear guidance on public life and social justice. Indeed, as C. Stephen Evans notes:

Kierkegaard's discourses are not focused at all on social changes or resolving social problems. They are entirely focused on the development of "inwardness" in individuals, addressed as they are to the "single individual" whom Kierkegaard "with joy and gratitude" calls his reader (see Kierkegaard 1990a, p. 5). The 
focus is not on transforming the world but on the transformation of the character of individuals.

(Evans 2019, p. 92)

One might rightly ask, then, whether Kierkegaard, even if instructive for theological anthropology or at the level of personal virtue, ${ }^{5}$ is helpful in a time where it is precisely one's public presentation as articulated according to embodied categories that so often frames our narratives of selfhood. Can Kierkegaard's notion of "the single individual" speak to the existing individuals who today are so rightly concerned about signification in terms of historically significant embodied categories of power and exclusion?

I think that it can, but despite what I will argue here, it is entirely reasonable, at least initially, to conclude that the answer is "no". Indeed, given Kierkegaard's location of the category of the single individual as a "religious" conception, he seems to indicate that there is no way for it to apply to matters of political existence. Consider, for example, the opening to his essay, "The Individual", which was published with Point of View, and consists of a preface, two "notes" written in the period 1846-1847, and a postscript on those two notes written in March of 1855. In the preface, he writes, "In these times politics is everything" (Kierkegaard 1962, p. 107). Having just lived through the (continuing) COVID pandemic, social movements such as Black Lives Matter and \#MeToo, the January 6th Capitol Insurrection, the rise of QAnon, and the continuing consequences of Trumpism, hardly a better description of the contemporary world could be offered. Yet, Kierkegaard continues on to use this description as a means of demarcating his own work as speaking to something else entirely:

In these times politics is everything. Between this and the religious view the difference is heaven-wide (toto caelo), as also the point of departure and the ultimate aim differ from it toto caelo, since politics begins on earth and remains on earth, whereas religion, deriving its beginning from above, seeks to explain and transfigure and thereby exalt the earthly to heaven.

(Kierkegaard 1962, p. 107)

Notice the way that he distinguishes between what motivates (as origin and aim) politics and religion. In light of such a claim, charges of worldlessness definitely seem to find some traction.

Yet, Kierkegaard goes on to make the staggering suggestion that the "worldliness" of politics will never be able to understand equality for all persons (Kierkegaard 1962, pp. 1078). "For if complete equality", Kierkegaard explains, "were to be attained, worldliness would be at an end" (Kierkegaard 1962, p. 108). Instead,

it is only religion that can, with the help of eternity, carry human equality to the utmost limit - the godly, the essential, the non-worldly, the true, the only possible human equality. And therefore (be it said to its honour and glory) religion is the true humanity.

(Kierkegaard 1962, p. 108)

Kierkegaard's claim that religion is the very condition of human equality (or said slightly otherwise, that human equality is a religious conception) is a view that is repeated throughout his authorship, but especially in the later discourses, where he explicitly articulates the notion of Christian spirituality (see Evans 2019). So, despite Kierkegaard's rhetorical rejection of the political sphere as being of any concern to his thought, a lot depends on what he means by "political" — and it is important not to push Kierkegaard too far into a position that we might wish he had occupied. ${ }^{6}$ When Kierkegaard is critical of politics, he does not dismiss lived, and embodied, historical human existence, but simply a particular authority from which such existence is understood to receive its significance: the crowd. 


\section{From Crowd to Community}

Attending to the role that finite existence, and the perspectival epistemology that results from it, ${ }^{7}$ plays in Kierkegaard thought is crucial for appreciating the way that his rejection of "politics" is not a refusal of historical determinacy. Instead, it is precisely the opposite. Kierkegaard is critical of politics as not being essential to human existence precisely because it so often eliminates the singularity of our lived existence itself. Rather than giving place to who we are, and inviting us into the risky task of "becoming a self," politics, he thinks, replaces a concern for qualitative singularity with the quantitative anonymity of the crowd.

Throughout his authorship, Kierkegaard (in his own name and via a variety of pseudonyms) stresses the decisiveness of "existence" as the condition of meaning, value, knowledge, and agency. Key to Kierkegaard's notions of "becoming a self", the appropriation that characterizes truth as "subjectivity", the passionate interiority of "faith", and even the definitional assertion that human beings are "spirit", is the idea that existence is defined by finitude, limitation, and ultimately death. ${ }^{8}$ Evans nicely articulates the link between spirit and historical meaning as follows:

We can now understand why it is that humans, if they are to be spiritual creatures, must be temporal creatures, who become themselves through a process. It is only in this way that humans can have even a relative degree of independence and autonomy, in which they have a say in who they are by participating in the process by which they become themselves.

(Evans 2019, p. 9)

It is the process of historical becoming, and in light of the existential arrows that attend it, that meaning-making emerges as a fragile good. In other words, because human beings "become", it matters what we do, what we believe, and what we choose. If everything were guaranteed from outside, or determined by external authorities, then our own existence would not be of any essential importance, but merely a contingent reality of no overriding consequence. We would be robots, not spirits. Hence, "for a finite being to be spiritual", Evans concludes, ". . . that being must go through a process of becoming, in which the being's own choices make a difference" (Evans 2019, p. 9).

With Evans, we must admit that only in light of this fact that all humans are "poor existing spirit[s]" (Kierkegaard 1992, pp. 189-90) does it make any sense to suggest that the task of becoming defines our lives. Notice, though, that becoming is something only possible within history - as we navigate the temptations of aesthetic immediacy and ethical abstraction. Religious existence is not, Kierkegaard insists, a once and for all sort of thing, but instead a constant attempt to make the right decisions in light of the very real risks of mistake, missteps, and failure that remain constant companions. "Without risk, no faith", Kierkegaard's Johannes Climacus writes (Kierkegaard 1992, p. 204; see also pp. 209-10). "Faith", he continues, "is the contradiction between the infinite passion of inwardness and . . . objective uncertainty" (Kierkegaard 1992, p. 204). Why is there such objective uncertainty? The answer, quite readily, is that we are not able to get outside of our lived contexts to know about existence as a stable epistemic object. Climacus explains that it is precisely this perspectival determinacy that is the "absolute difference between God and a human being" (Kierkegaard 1992, p. 217):

A human being is an individual existing being (and this holds for the best brain just as fully as for the most obtuse), whose essential task therefore cannot be to think sub specie aeterni, because as long as he exists, he himself, although eternal, is essentially an existing person and the essential for him must therefore be inwardness in existence; God, however, is the infinite one, who is eternal.

(Kierkegaard 1992, p. 217)

Due to this distinction between an infinite God and finite humanity, Kierkegaard is able to stress the uniqueness of the person of Christ, the God-man, as the "absolute paradox" - viz., the infinite existing in time. Historically existing as spiritual beings in the 
process of becoming who they are, humans are individualized qualitatively, not merely quantitatively. It is the quantitative logic of the crowd that Kierkegaard will oppose as being the primary reason that he is unconcerned with political life. Yet, we should not confuse politics here with embodied living and the situational contexts in which it plays out. ${ }^{9}$

In the same series of notes in which Kierkegaard situates the single individual as a religious conception over against any political concern, he positions the crowd as the "untruth" that stands opposed to Christianity's "well-thought-out view of 'Life', of 'the Truth', and of 'the Way"' (Kierkegaard 1962, p. 110) ${ }^{10}$. Like Martin Heidegger's later notion of "the they", which draws deeply upon Kierkegaard's notion, the key aspect of the crowd is not simply that there is more than one person, but that quantitative judgment, as such, overwhelms qualitative dignity. The crowd emerges when there is a "decisive significance" that is "attached to the fact that there is a multitude" (Kierkegaard 1962, p. 112). When such quantitative status overrides the singularity of the single individual, what results is "abstraction", "cowardice", and "anonymity" (Kierkegaard 1962, pp. 113-16). Whereas the single individual is "marked" by the truth, the crowd is "the abstract, the fantastical, the impersonal" (Kierkegaard 1992, p. 117).

When people join with the crowd, they lose themselves. Rather than being invested in the existential task of becoming singular individuals, they are not much more than particular instantiations of some larger category (what Kierkegaard will call "specimens"). When lost in this way, the single individual is not heralded in her identity as a poor existing spirit, but instead becomes "nobody" (Kierkegaard 1962, p. 116). Yet, just like the anonymity of what he variously terms "the public" and "the press", Kierkegaard indicates that when individuals become nobodies, they lose all responsibility (Kierkegaard 1962, p. 116). Instead of the spirited investment in the significance of existential decision, one's decision becomes irrelevant in light of the crowd, the majority, the multitude. Here, we see that quantity, itself, becomes the standard of significance such that truth is abandoned in the name of popularity. The crowd is untruth because it "confounds vox populi with vox dei" (Kierkegaard 1962, p. 135). ${ }^{11}$

It makes sense then, when politics is linked to the logic of the crowd, why Kierkegaard's emphasis on the single individual as "the prime condition of religiousness" (Kierkegaard 1962, p. 127), and as "the decisive Christian category" (Kierkegaard 1962, p. 133), would be explicitly situated "as opposite to politics" (Kierkegaard 1962, p. 132). Nonetheless, the opposition between religion and politics is neither a rejection of historical existence, nor a disregard for the socio-cultural situations in which we find ourselves existing. It is instead a recognition of the way that political life is so often determined by external countable realities, rather than the qualitative significance of each individual before God. Kierkegaard's critique of politics is a matter of getting our priorities straight, rather than an endorsement of escapism or acosmism. As spirit, the single individual always stands before God in existence. Becoming a self is never completely abstracted from where one finds oneself in a temporal, historical, and social location.

In a series of footnotes, Kierkegaard directly addresses this point. The first is offered as a clarification when he first distinguishes the Christian way, truth, and life, from the view of life that receives its meaning from the crowd. There he writes "Perhaps it may be well to note here once and for all a thing that goes without saying and which I have never denied, that in relation to all temporal, earthly, worldly matters the crowd may have competency, and even decisive competency as a court of last resort" (Kierkegaard 1962, p. 110). He notes that throughout his authorship he has never denied the importance of things like voting, majoritarian decision, and deliberative arbitration in social matters. Such concerns are just not what underwrite his own religiously oriented thinking: "It is not of such matters I am speaking, nor have I ever concerned myself with such things. I am speaking about the ethical, about the ethico-religious, about 'the truth', and I am affirming the untruth of the crowd, ethico-religiously regarded, when it is treated as a criterion for what 'truth' is" (Kierkegaard 1962, p. 110). Kierkegaard appreciates that there are times when collective decision is necessary for historical social life, but such collective decision 
cannot determine the significance of an individual person. An individual does not matter because they are recognized by the crowd, but because they are known by God where they are. Popularity, material wealth, and social status are not what makes someone matter. Instead, in a kenotic inversion of the logic of the crowd, an individual matters, before God, regardless of social station. It is this basic point that makes Kierkegaardian identity theory relevant to contemporary identity politics.

Recognizing that his account might be misinterpreted as defending radical isolationism, Kierkegaard clarifies that the very possibility of preaching requires an audience and so gathering together is not, itself, the problem. The gathering would problematically become a crowd at the moment when it thinks the "truth" that should be preached will be authorized by "the ballot" (Kierkegaard 1962, p. 110). Religious truth is not determined by the majority, but it does get presented, discussed, believed, and lived out in the context of gathering together. In order to try to find a way of distinguishing things here, I would suggest that Kierkegaardian identity theory rejects the crowd, but embraces community. Community, in this sense, occurs when we lean into the responsibility that singularizes us as individuals and positions us as neighbors. Whereas the crowd turns us into nobodies and "renders the individual completely impenitent and irresponsible", the community is glimpsed in the love command and the equality of all of humanity announced by God's invitation to "every man, absolutely every man" (Kierkegaard 1962, p. 127). ${ }^{12}$

I recognize that any proposal of a Kierkegaardian community is a fraught idea. Indeed, scholars are quite at odds on how to understand Kierkegaard on this front (see Connell and Evans 1992). Given Kierkegaard's explicitly religious focus, the most prominent objection to my suggestion again concerns the charge of radical individuality that is so often presented as crucial for faithful existence. Whether in the existential mode found in the Postscript or the soteriological mode found in Fear and Trembling, the focus on subjectivity and faith as not matters of public life couples with Kierkegaard's lack of any sustained focus on ecclesiology such that there are good reasons to think that it is wrong to attribute to him a positive view of community. Bringing these existentialist and ecclesiological threads together, Stephen Backhouse notes that "Behind Kierkegaard's attacks on both the 'State' and 'People's Church' formulations in Danish Christendom lies a deeper criticism against congregations of all sorts" (Backhouse 2011, p. 216). While acknowledging such difficulties, and again not wanting to push things too far, I side with those who do find in Kierkegaard a form of community - especially in regard to Christianity-that may speak to broader notions of sociality. This view is represented well by Michael Tilley:

The open-ended character of Kierkegaard's community appreciates differences between persons without sacrificing communal belonging. Common beliefs, practices, and goals play a crucial role in the origin and development of a community and as a result, they are valuable for communal life; but these original conditions ultimately give way to a type of social relationship that is maintained independently of those original conditions.

(Tilley 2013, p. 406)

In order to develop the idea of Kierkegaardian community a bit more, I suggest that Stephen Backhouse's suggestion of a Kierkegaardian Christian "neighborhood" is quite helpful (Backhouse 2011, pp. 218-21). Backhouse's constructive claim is that "Kierkegaard's attacks on 'congregation' need not be read as attacks on all 'sociality' as such" (Backhouse 2011, p. 219). Consistent with the critique of the crowd that I have highlighted in Kierkegaard's opposition to politics, narrowly understood, Backhouse claims that "the possibility of inter-personal social relations is only denied if we conceive of the Church as a crowd of 'people-like-us' who find strength in numbers" (Backhouse 2011, p. 219). "Kierkegaard's attack on the deified congregation", he continues, "does not render him a proponent of anti-social isolation. This is not a complaint with social agreement as such, but rather a conflict of open-endedness versus absolutization" (Backhouse 2011, p. 219). Aligned with the idea that selfhood is always a matter of becoming, Backhouse presents Kierkegaard's notion of a neighborhood, or a neighborly community, as distinct from the 
congregational crowds in a way that neither forgets individual identity in the anonymity of the crowd, nor reduces identity to a matter of social status.

When we read Kierkegaard in this way, a variety of texts then become openings for such neighborly community. For example, the Communion discourses are invitations for "all" to "come" to the table, not simply for "me" or "you" to come. Further, Practice in Christianity and Works of Love are not simply about one's relationship to God, but about how we are to relate to each other in light of God's relation to us all. Finally, as I have argued elsewhere, even the seemingly radical individuality of Abraham only signifies against a background condition of his continuing relationships with Sarah, Isaac, and others (see Simmons 2007). Ultimately, the single individual is not essentially opposed to community/neighborhood, but to the way that the crowd eliminates the singularity of becoming. The neighborly community consists of single individuals who continue to realize the historical context in which their becoming occurs. As Kierkegaard explains, "the single individual relates himself first to God and then the community, but this first relation is the most important, even though the single self does not reject the second" (Kierkegaard 1967, vol. 4, p. 4110).

Building on Backhouse's general proposal and Kierkegaard's own account, then, communal relationship is not abandoned by those who understand human equality to occur only in relation to God. Hence, a Kierkegaardian concern for religious existence continues to admit the importance of social life while rejecting social status as a determination for one's relation to God. Listen to Kierkegaard in this respect:

The reader will also remember that here the word "crowd" is understood in a purely formal sense, not in the sense one commonly attaches to "the crowd" when it is meant as an invidious qualification, the distinction which human selfishness irreligiously erects between "the crowd" and superior persons, \&c. Good God! How could a religious man hit upon such an inhuman equality! No, "crowd" stand for number, the numerical, a number of noblemen, millionaires, high dignitaries, \&c.- as soon as the numerical is involved it is "crowd", "the crowd".

(Kierkegaard 1962, p. 112)

Yet, again, Kierkegaard's criticism is directed toward the quantitative as an external criterion. However, importantly, while making this point, he eschews anyone who would think that he is giving into the worldly temptation to think that elevated socio-economic status would deliver one from the grips of the crowd. The crowd is not the unwashed masses, as it were; it is not the rabble without the means to distinguish themselves as important enough to stand out as individuals (due to wealth, power, or status). Instead, Kierkegaard actually acknowledges the reality of the temptation to view people as lesser due to such socio-economic location and calls it irreligious selfishness. In this way, Kierkegaardian identity theory, like contemporary identity politics, attempts to defend the moral dignity of all existing individuals precisely by attending to the ways that power tends to minimize and marginalize some while elevating others. In this note, Kierkegaard condemns what we would now term "privilege" whenever it is taken for granted as the location of one's importance. This is where the religious category of "human equality" signifies as an invitation to rethink politics itself as non-ultimate, rather than an encouragement to disengage from all historical matters of sociality.

The human equality that is made possible when each person is viewed as a single individual is an acknowledgement that no one is reducible to what is said about them by "the crowd" as a manifestation of historical power structures. However, in order to escape the ultimacy of such power structures, God must stand as the middle term so that one's relation to others is a relation between neighbors: single individual to single individual. "To honour ever man, absolutely every man", Kierkegaard writes-again deploying that repetitive phrase that is meant to express radical inclusivity-"is the truth, and this is what it is to fear God and love one's neighbor" (Kierkegaard 1962, p. 118). Neighbor-love is not a worldly possibility, but a religious opening that shifts from the crowd to the community: 
In case every one were in truth to love his neighbor as himself, complete human equality would be attained. Every one who loves his neighbor in truth, expresses unconditionally human equality. Every one who, like me, admits that his effort is weak and imperfect, yet is aware that the task is to love one's neighbor, is also aware of what human equality is.

(Kierkegaard 1962, p. 118)

Of what does such "neighbor-love" consist? Kierkegaard's answer is again a striking rebuke of all social grandstanding: "The thing is simple enough: this thing of loving one's neighbor is self-denial" (Kierkegaard 1962, p. 118). Self-denial. Humility. We might term these the virtues of diversity and inclusion such that they are reminders that your identity is never established by marginalizing or ignoring the identity of another. ${ }^{13}$ Instead, we are singularized when we recognize every other person as "neighbor". ${ }^{14}$ Rather than patient hospitality to the neighbor in light of one's own self-denial, the crowd encourages the minimization of others who are not like you. The crowd is "the way to material power, the way to temporal and earthly advantages of all sorts - at the same time it is the untruth" (Kierkegaard 1962, p. 118). It is untruth because of its mistaken prioritization of worldly status as determinate of identity. Becoming a self is not the same thing as becoming rich. Becoming a self is not achieved at the cost of minimizing others. Becoming a self, according to Kierkegaardian identity theory, is about resisting the temptation to worldly privilege in order that you might find yourself in a personal relationship with a personal God who commands you to love all other persons (and probably quite a few non-human others as well) (see Kierkegaard 1962, p. 118).

\section{Two Critical Objections}

Before moving on to consider a Biblical case study consistent with this Kierkegaardian identity theory, and then turning to intersectionality theorists to bring this Kierkegaardian view into conversation with the contemporary debates, I want to raise and respond to two objections. Both of these critical concerns are serious, reasonable, and grounded in Kierkegaard's own texts. The first problem is that his view might indicate a kind of identity blindness, and the second worry is that his critique of "alliances" in Works of Love puts him at odds with any notion of identity politics, as such.

1. Identity Blindness Objection: At the beginning of the first "note" in "The Individual", Kierkegaard seems to invite a sort of identity blindness akin to something like a Rawlsian veil of ignorance. If this indeed what he is doing, then it would seem that any attempt to see resources in his thought for contemporary identity politics would be limited indeed. Well, listen to what he says there: "My dear, accept, I pray, this homage. I make it blindfold as it were, but therefore sincerely, undisturbed by respect for persons. Who thou art I know not, where thou art I know not, what thy name is I know not. Yet thou art my hope, my joy, my pride; although unknown thou art an honour to me" (Kierkegaard 1962, p. 109). Reading this passage as an affirmation of identity blindness would seem to be consistent with Kierkegaard's later claim that the crowd is a matter of affirming "the distinctions of human life" (Kierkegaard 1962, p. 119). In light of such passages, it appears that there are serious obstacles facing the reading that I am attempting to offer. Even if not a radical individualist, Kierkegaard seems explicitly to reject any concern for embodied distinctions such that he can address his reader, the single individual, without knowing even that individual's name.

Although I acknowledge that these are tricky passages, I do not think that they are finally the defeaters that they might initially seem. Rather than calling for an indifference of embodied historical identities, Kierkegaard here is simply positioning himself as only able to operate within a finite embodied perspective. However, even without such embodied knowledge of his reader's name, he affirms his investment in that person. The reader, as single individual, is his hope, joy, and pride. How so? Insofar as that person lives into the religiously framed existence that his authorship attempts to highlight as the proper mode of human equality. Unable to know his reader, he is also speaking to "every person, absolutely 
every person" in that regardless of how they are defined by the historical workings of material and social power, they are poor existing spirits all called to become selves. In a striking contrast to Kierkegaard's professed ignorance of the embodied identity of his reader, and in repetition of the distinction between God and humans, he claims that God is not similarly limited:

But eternity which arches over and high above the temporal, tranquil as the starry vault at night, and God in heaven who in the bliss of that sublime tranquility holds in survey, without the least sense of dizziness at such a height, these countless multitudes of men and knows each single individual by name.

(Kierkegaard 1962, p. 112)

In a direct contrast to the anonymity of the crowd, God knows "each single individual by name". Importantly, though, God also knows these single individuals despite the "countless multitudes" in relation to which they risk being "named" as "nobody". Kierkegaard's "blindfold" is, thus, not best understood as an affirmation of an essentialist veil of ignorance, but instead an insistence that one's privilege or lack thereof does not define who you are. ${ }^{15}$ To my mind, I think that on this point, he is quite close to someone like Martha Nussbaum (1999) who, precisely because she does take seriously the embodied realties that attend gender, race, sexuality, and disability, stresses the importance of not allowing those realities to be foundational to one's moral dignity. If they were allowed to become idols of moral life, then we would risk changing the direction of the crowd's judgment about truth, but not subverting the crowd as the standard of such judgment.

2. Alliances as Self-Love Objection: Kierkegaard's most expansive and sustained consideration of Christian norms for social life arguably occurs in Works of Love. ${ }^{16}$ Therein, Kierkegaard develops a distinction between the religious orientation toward eternity and the political orientation toward temporality. Locating neighbor-love as solidly defined by the "perfections of eternity", he suggests that it is this difference that explains why neighbor-love is so thoroughly out of step with the priorities and concerns of political life (Kierkegaard 1995, p. 69). Repeatedly referring to the "dissimilarities of earthly life", Kierkegaard goes so far as to say that social separation based on such dissimilarities amounts to "depravity" and reflects a kind of "paganism" (Kierkegaard 1995, p. 69). Consider the following representative passage:

in paganism people are inhumanly separated one from another by the dissimilarities of earthly life or by the caste system, how this ungodliness inhumanly teaches one human being to disclaim kinship with another, teaches him presumptuously and insanely to say of another human being that he does not exist, is "not born".

$$
\text { (Kierkegaard 1995, p. 69) }
$$

Admittedly, when taken in isolation, it does seem like this would spell trouble for Kierkegaardian identity theory. Moreover, later in Works of Love, Kierkegaard develops the idea of an "alliance" in which a group of individuals who share some degree of commonality come together in an earthly unity (see Kierkegaard 1995, p. 119). Such alliances lack the perfection of eternity because they are entirely understandable according to the worldly logic of self-love, rather than the self-denial required for neighbor-love. "What the world honors and loves under the name of love is an alliance in self-love", he writes (Kierkegaard 1995, p. 119). "The alliance", he continues,

also requires sacrifice and devotion on the part of the one it will call loving; it requires that he sacrifice a portion of his own self-love in order to hold together in the united self-love, and it requires that he sacrifice the God-relationship in order to hold together in a worldly way with the alliance that excludes God or at most takes him along for the sake of appearance.

$$
\text { (Kierkegaard 1995, p. 119) }
$$

Although it would be reasonable for someone to suggest that such passages are troubling for the proposal I have developed here, I do not think that such an interpretation 
is the best option for how to read these texts. Indeed, immediately after referring to the potential paganism of social separations based on dissimilarities of earthly life, Kierkegaard makes it explicit that

Christianity has not taken away the dissimilarity any more than Christ himself would take or would ask God to take the disciples out of the world-and this amounts to the same thing. No person has ever lived in Christendom, any more than in paganism, who is not dressed or cloaked in the dissimilarity of earthly life. Just as little as the Christian lives or can live without the body, so little can he live without the dissimilarity of earthly life that belongs to every human being in particular by birth, by position, by circumstances, by education etc.-none of us is pure humanity.

(Kierkegaard 1995, p. 70)

Notice that the distinction between paganism and Christianity, here, is the way that such dissimilarities are allowed to function internal to social differentiation. Christianity rejects social separations such as the caste system that would make an individual or group better or worse than others due to such dissimilarities. By saying that none of us can live without bodies, Kierkegaard appreciates the embodied differences that so often do lead to depraved versions of sociality whereby some are endowed with power, privilege, and status, while others are excluded from opportunities, access, and dignity. Rather than "insanely" saying of another human that she does not exist due to the marginalization resulting from an embrace of earthly dissimilarities as reflective of one's value, Christianity, Kierkegaard contends, sees every other as equal in the eyes of God. Such equality neither amounts to identity blindness nor to a denial of earthly dissimilarities. Rather, the perfections of eternity are what makes possible loving others precisely in their dissimilarities. The "temptation of dissimilarity" is to let such embodied differences lead us to the conclusion that some bodies count as more than others. Kierkegaardian identity theory views marginalization as a failure of neighbor-love, but it does not offer love at the cost of thereby ignoring the historical markers of embodiment (Kierkegaard 1995, p. 70).

Nonetheless, even critical of the historical workings of embodied privilege, we must guard against sliding too far in the opposite direction such that the poor are viewed as necessarily virtuous, or that a commitment to overcoming white supremacy requires the view that all people of color are somehow faithful, etc. Kierkegaard explicitly rejects such overcorrection and does so by directly resisting the charge of identity blindness itself. It is by invested attention to others that we enact God's love for us:

Christianity is neither blind nor one-sided; with the calmness of eternity it surveys equably all the dissimilarities of earthly life but does not divisively take sides with any single one. . . . Dissimilarity is like an enormous net in which temporality is held; there are in turn variations in the meshes of this net-one person seems more trapped and bound in existence than another; but all this dissimilarity, the dissimilarity between difference and difference, this comparing dissimilarity, does not preoccupy Christianity at all.

\section{(Kierkegaard 1995, p. 71)}

Kierkegaard is not simply reducing Christian neighbor-love to a matter of worldly politics. However, the general identity theory that we can parse from his authorship is one that does appreciate distinctiveness in a way that allows for a rejection of privilege as a distinction that makes a difference to one's righteousness. Although the privileged can be Christian and the marginalized can give in to depravity, Christianity encourages us to realize that "love is not a being-for-itself quality but a quality by which or in which you are for others" (Kierkegaard 1995, p. 223). Being for others cannot be understood outside of an appreciation of the history in which embodiment has signaled status for some and the lack of it for others. Positioning God as the "middle term" in our loving relationships with others allows us to see others as they are, not as we would hope that they would be. Embodied distinctiveness matters because lived existence does. "It is also in 
the relationships of love among human beings", he explains, "only true love loves every human being according to the person's distinctiveness" (Kierkegaard 1995, p. 270).

It is only in the context of such "true love" that sees, and loves, the other in her distinctiveness that we can appreciate how the idea of "alliances" are not the same thing as communities/neighborhoods committed to loving those who have been insanely declared unlovable by the prevailing social norms. The problem with alliances, Kierkegaard makes clear, is that they are unities defined by self-love. They reinforce one's own identity as the expense of someone else's such that one's own dissimilarities become normative for others: "If the rigid and domineering person cannot ever create, he wants at least to transform - that is, he seeks his own so that wherever he points he can say: See, it is my image, it is my idea, it is my will" (Kierkegaard 1995, p. 270). In the context of the United States, for example, which unfolds in light of a history of slavery and segregation, this Kierkegaardian idea can be read as a way of challenging the structural functioning of "whiteness" as normative for social life. Or, given the history of patriarchy and heteronormativity as so socially prevalent, his critique of alliances should invite an awareness of the insidious temptation toward adopting a heteronormative "male gaze" as invisibly normative in ways that dehumanize some in light of a circumscribed conception of humanity. Importantly, such racist, patriarchal, and homophobic approaches forget that "none of us is pure humanity", as Kierkegaard says. As such, we need others in order to have a better sense of ourselves. His claim here stands as a moral supplement to the perspectivalist epistemology that attends finitude.

Rather than forming alliances that develop self-love at the cost of ignoring God, Kierkegaardian identity theory encourages appropriate self-love such that neighbor-love is anchored in an appreciation of one's own status before God. For Kierkegaard, God not only knows the name of the other, but knows mine too. As such, distinctiveness, when not allowed to become a rationale for elevating some above others, but instead understood as a recognition of the eternal equality of all, regardless of position, should be embraced as a divine gift. "To have distinctiveness", he writes, "is to believe in the distinctiveness of everyone else, because distinctiveness is not mine but is God's gift by which he gives being to me, and he indeed gives to all, gives being to all" (Kierkegaard 1995, p. 271). We must not miss the repetition of "to all" here. Kierkegaard again stresses the fact that when we show hospitality to all others, we also are included in the welcome.

Even assuming that I have developed a possible account of Kierkegaardian identity theory and at least offered plausible responses to some textual objections that could be raised, one could still object that Kierkegaard himself might indeed leave open room for a concern for embodied difference, but he does not ever fill in this view with specific examples. Indeed, the occasional examples I have offered above have, admittedly, been quite speculative. I actually find such an objection to be fair and acknowledge that we need to turn elsewhere for a concrete case study of how a focus on the single individual would also incorporate an awareness of, and attention to, embodied realities such as race gender, and sexuality. As such an example, I think that it is helpful to turn to a scriptural story with which Kierkegaard was no doubt familiar: the encounter between Jesus and the Samaritan woman in John $4 .{ }^{17}$

\section{The Samaritan Woman: A Biblical Case Study}

John 4 opens by challenging the comparative logic by which the quantitative standard of the crowd operates. The Pharisees had heard that "Jesus is making and baptizing more disciples than John"; they seemed to use such information in order to present Jesus and John as rivals (John 4:1-2, NRVS). Wanting nothing to do with such comparative calculation, Jesus "left Judea and started back to Galilee" (John 4:3, NRVS). John then recounts that the path Jesus took on his journey required that he go through Samaria. Admittedly, it could be that John just provides this detail in case his readers are interested in geography, but more likely he records this detail in order to give context to the personal encounter that was about to occur between Jesus and a woman by a well. Jesus stopped at the well due to 
being "tired out by his journey" and the woman, meanwhile, "came to draw water" (John $4: 4-7$, NRSV). Interestingly, John also provides the detail that "it was about noon" (John $4: 6$, NRSV). Ostensibly, it makes sense that Jesus would stop at the well in the heat of the day during his travels in order to get a drink, but why would a woman who lived nearby choose to come out at the hottest part of the day in order to engage in the physical labor required to draw water? Over the course of the chapter, we come to learn that the woman has quite a reputation in the local community. She comes to the well in the middle of the day, it seems, to avoid the judgment of the crowd.

Notice that John is clear that the person who came to the well that day was "a Samaritan woman" (John 4:7-8, NRSV). This is important because according to the social norms of the time, it would be quite rare for Jesus even to engage with an unknown woman at all just due to the gender difference. This explains why, when they arrived at the well, the disciples "were astonished that he was speaking with a woman" (John 4:27, NRSV). Moreover, not only her gender but her ethnicity is important for tracking with the drama of the encounter. The historical relationship of the Jews and Samaritans was extremely complicated and characterized by resentment and long-standing animosity. ${ }^{18}$ Samaritans were largely rejected by Jew and Gentile alike. Given these social norms that would dictate Jesus's dismissal of this person due to such embodied realities, when Jesus asks the woman for some water, she is not unaware of how odd his request is: "The Samaritan woman said to him, 'How is it that you, a Jew, ask a drink of me, a woman of Samaria?' (Jews do not share things in common with Samaritans)" (John 4: 9, NRSV).

Part of the discussion between Jesus and the Samaritan woman speaks precisely to the historical division between the Samaritans and Jews over the proper location for worshiping God (John 4:19-20, NRSV). Jesus's responses throughout this engagement are rightly read as ruptures of the operative political logic of that day. Yet, it is because Jesus acknowledges all of the embodied realities that attended the woman's identity that his comments to her as a single individual stand out as so subversive. Regarding the theological differences between Jews and Samaritans, Jesus refuses to come down on either side of the debate regarding worship location, but instead expresses radical hospitality that appreciates her embodied identity while positioning human equality beyond ethnic or gendered difference. He tells her that "the hour is coming, and is now here, when the true worshipers will worship the Father in spirit and truth, for the Father seeks such as these to worship him" (John 4:23, NRSV). Although there are a variety of ways to make sense of Jesus's claim here, the text certainly leaves open the following interpretation offered in The Message paraphrase: "the time is coming - it has, in fact, come-when what you're called will not matter and where you go to worship will not matter" (John 4:23, MSG). Two things are important here. First, in the NSRV and also the MSG, we see that Jesus declares that the view he offers is not something that remains located in an eschatological ideality, but instead is a present reality: "the hour is coming, and is now here". Crucially resisting readings of Christian social existence that would suggest the call of Christ is to transcend the world, here we see John reject such a "worldless" notion of the Gospel. Jesus declares it is true now precisely because it is eternally the case. As Kierkegaard repeatedly notes, the religious intervention in political life is a rupture of the temporal by eternity. So, here in Jesus's claim, we find the Absolute Paradox professing that Christianity inaugurates not only something yet to come, but already fractures our social imaginations in order to allow us to see things otherwise even right where we are.

This eternally infused temporal immediacy opens onto the second point worth noting here. Jesus demonstrates that the single individual is not reducible to an historical what, but instead is located in the spiritual who that one is becoming. In this passage, Jesus transitions from the initial focus on embodied determinacy (i.e., a Samaritan who worships differently from the Jews) to an emphasis on her existential decisions as a poor existing spirit (who is, like all others, essentially determined as standing before God). In this way, the Samaritan woman is situated in relation to God as spirit to Spirit: "God is spirit, and those who worship him must worship in spirit and truth" (John 4:24, NRSV). This last idea 
is one that Kierkegaard frequently mentions and it connects with the famous distinction drawn by Climacus in Postscript that objectively the emphasis is on what, but subjectively it is on the how. Again, The Message paraphrase helps to illuminate a possible way of making sense of this otherwise hermeneutically opaque passage and it does so in a decidedly Kierkegaardian way:

It's who you are and the way you live that count before God. Your worship must engage your spirit in the pursuit of truth. That's the kind of people the Father is out looking for: those who are simply and honestly themselves before him in their worship. God is sheer being itself-Spirit. Those who worship him must do it out of their very being, their spirits, their true selves, in adoration.

(John 4:23-24, MSG)

In that last line, Jesus connects the who to the how. Her decisions matter. Her historical existence is marginalized by oppressive power structures and identity categories and yet he affirms her equal position before God. Jesus sees the Samaritan woman not as abstract or anonymous, but as located and embodied. Here, Jesus, like Kierkegaard, does not ignore the social categories that affect the lives that we live as existing beings, but refuses to grant those categories finality in who it is that we are. The Samaritan woman might be scorned by the crowd, but Jesus invites her to sit and share a drink with him. This is what true human equality looks like and stands, I suggest, as a productive example of how Kierkegaardian identity theory would work in practice.

Kierkegaard does not conceive of equality as finally possible within the sphere of politics because he rightly recognizes that an inversion of one power structure will just set up another one-this is why he warns against overcorrecting in our view of dissimilarities and resists allowing communities to reduce to alliances. Rather than arguing for a particular model of power as more virtuous than other alternatives, Kierkegaard repeatedly presents the kenotic logic exemplified by the example of Jesus as the paradigm for neighbor-love and the prototype for faithful existence. Such a presentation of Jesus is not simply of theological importance, but also offers a radical contrast to what sociality means and how equality is possible as a lived reality.

Given that equality is a key idea within social and political theory, Kierkegaard's relocation of equality as a religious conception is relevant to such debates. Indeed, at least part of what identity politics, or, as Iris Marion Young put it, "the politics of difference" (Young 1990), ${ }^{19}$ attempts to achieve is a greater recognition of equality as a moral and social good. With that in mind, I think it is important for us to be willing to push Kierkegaardian identity theory a bit further than Kierkegaard himself might have been willing to go. In order to take such a speculative, and yet constructive, step, I suggest that there are two aspects of identity politics that offer especially fecund points of contact with a Kierkegaardian account of the single individual: standpoint and intersectionality theory.

\section{Collins, Crenshaw, and Kierkegaard}

There is no way to offer a developed account of intersectionality and standpoint theory here, but let me just mention some of the highlights in order to sketch how Kierkegaardian identity theory can benefit from these ideas. I offer this simply as a suggestion that will hopefully lead to further work by others who can pursue more detailed ways forward.

In her landmark book, Black Feminist Thought, Patricia Hill Collins (2000) opens the preface by noting that when she was five years old that she was "surrounded by children like [her]self-the daughters and sons of laborers, domestic workers, secretaries, and factory workers" and that they "affirmed who [she] was" (Collins 2000, vii). Additionally, "all of the grown ups" provided her with "words and hugs" that "made [her] feel that [she] was important and that what [she] thought, and felt, and accomplished mattered" (Collins 2000 , vii). Notice the way that Collins understood her identity as singular, but still within the context of a community—surrounded by what Kierkegaard might term people who saw her as a neighbor. However, then as she grew up and her "world expanded", she had to navigate her identity in a space where the community gave way to the crowd, for 
whom her race and her class made her less significant, less worthy, and less important. ${ }^{20}$ As Collins recounts:

I saw nothing wrong with being who I was, but apparently many others did. My world grew larger, but I felt I was growing smaller. I tried to disappear into myself in order to deflect the painful, daily assaults designed to teach me that being an African-American, working-class woman made me lesser than those who were not. And as I felt smaller, I became quieter and eventually was virtually silenced.

(Collins 2000, vii)

Collins's personal narrative is all too familiar to those who find themselves in crowds who reduce their subjectivity to not much more than what Kierkegaard calls "specimens", instead of recognizing their essential (religious) equality as "individuals" (Kierkegaard 1962, p. 111). One of Collins's basic tasks in Black Feminist Thought is to illustrate the ways that "oppressed groups are frequently placed in the situation of being listened to only if [they] frame [their] ideas in the language that is familiar to and comfortable for a dominant group" (Collins 2000, ix). In harmony with Kierkegaard's description of the way that the crowd becomes the false standard, the criterion, and the authority, by which "truth" is decided in the context of political power, Collins notes that the "requirement" of oppressed groups to express themselves on the terms of those in power "often changes the meaning of [their] ideas and works to elevate the ideas of dominant groups" (Collins 2000, ix). In this way, we might, with Kierkegaard, say that Collins turns to intersectional standpoint theory as a way of challenging the "untruth" of the crowd.

The ultimate goal of Collins's text, and broader work, is "to help empower AfricanAmerican women" (Collins 2000, xi). She goes on to elaborate on what such empowerment will require:

the empowerment for African-American women will never occur in a context characterized by oppression and social injustice. A group can gain power in such situations by dominating others, but this is not the type of empowerment that I found within Black women's thinking. Reading Black women's intellectual work, I have come to see how it is possible to be both centered in one's own experiences and engaged in coalitions with others. In this sense, Black feminist thought works on behalf of Black women, but does so in conjunction with other similar social justice projects.

(Collins 2000, xi)

Aware of the ways in which empowering oneself requires empowering others, Collins speaks to the social dynamics that Kierkegaard would suggest attend to neighbor-love. Like Kierkegaard, Collins rejects the idea one can emerge from the anonymity of the power structures by which the crowd operates only by marginalizing someone else. Here, she attests to the importance of overcoming the crowd by finding genuine community in which one can be a single individual no longer determined by the logic of the dominant multitude.

It is crucial to acknowledge that Collins's community is one of social solidarity with specific aims at political outcomes. That is not typically the case for Kierkegaard. Like Kierkegaard, Collins sees selfhood as more than a matter of contingent social namingi.e., one's moral dignity is not produced by one's social status-but she is attempting to transform a structural reality, whereas Kierkegaard is attempting to highlight a theological one. Nonetheless, Collins's theory is not something that should be read as at odds with Kierkegaard's notion of the single individual. Instead, they are both critical responses to the mode in which the world tends to define who we are and who we are becoming. However, Kierkegaardian identity theory is unlikely to find the historical traction that it requires in order to become existentially transformative without being supplemented by the structural social focus provided by Collins (and many others).

Alternatively, however, Collins is depending on an underlying ethical (or ethicoreligious) account of the moral dignity and sacrosanct status of every person, absolutely 
every person, such that equality is an assumed "good", by which her quest for justice and empowerment of the marginalized and oppressed is then supported. Yet, her work generally takes such a view for granted, rather than filling in the details of how single individuals are the condition for human equality. In this way, I think that Kierkegaard and Collins are mutual resources for each other. It is unlikely that Collins would grant the explicitly Christian framework in which Kierkegaard situates himself, and it is unlikely that Kierkegaard would embrace the explicitly political focus of Collins's approach. Nonetheless, even if Kierkegaard and Collins, themselves, would not easily work together, these differences are not insurmountable for those of us who read them both as offering crucial resources for seeing others as neighbors and cultivating the humility required to undermine the idolatry of privilege.

Due to the workings of power, marginalization cuts in a variety of ways that resist easy characterization. Intersectional theory was originally developed by Kimberle Crenshaw in the 1980s (see Crenshaw 1991) to speak to the ways in which many scholarly and political attempts to work for justice tended to operate according to overarching groupings that ended up just serving to silence those voices who did not fit neatly into the categories. For example, as Collins and Crenshaw both illustrate, traditional feminism has tended to focus on white women, traditional race theory has tended to focus on black men, etc. Intersectional identity theory reminds us that identity is always individual because it is always complicated, dynamic, and plural. Moreover, marginalization and oppression are similarly felt in different ways by different people due to the compounding effects of overlapping identity categories that get narrated by power structures that are benefited by reducing singular identities (and the lived marginalization that they bear in and on their bodies) to a static narrative of this or that group, crowd, congregation, or alliance. Crenshaw has long advocated for the importance of seeing the people, especially black women, who are turned into "nobodies" by the dominant narratives and whose suffering is too often either invisible or ignored. Opposing the very deviant conception that Kierkegaard critiques as paganist erasures of other people, Crenshaw's work has led to a recent movement, \#SayHerName, which attempts to bring the individuals who have been victims of violence at the hands of power, to visibility as singular lives (see Crenshaw 2021). By saying the names of these black women, this movement has powerfully resisted the erasure caused by the logic of white supremacy that continues, tragically, to serve as a tacit criterion for social identity in America.

Let me stress, again, we would be wrong to suggest that Crenshaw's activism is doing the same work as Kierkegaard's religious philosophy. However, we would also be wrong to miss the opportunity to see the points where they resonate regarding selfhood and sociality. It is hard not to see \#SayHerName as a social manifestation of the Kierkegaardian idea that God knows the name of every single individual. Both Kierkegaard and Crenshaw highlight that the moral dignity of individual persons is threatened when we allow historical power structures to become the standard of such dignity - to determine its "truth" as Kierkegaard would say, due to the quantitative logic of majority privilege. Remember, it is the anonymity and irresponsibility of the crowd that Kierkegaard sees as being at odds with the single individual. Similarly, so long we live in a world where some individuals are unable to be viewed as neighbors because of the invisibility of their embodied identity, we have failed to enact what it means human equality to be a lived reality. As with Collins, Crenshaw's work helps us to avoid the temptation to allow Kierkegaard's explicit rejection of abstraction become, itself, all too abstract and detached from the perspectival, historical, embodied realities in which poor existing spirits live, move, and have their being-whether as Christians or not.

There remain a variety of points that need a bit of nuance in order for Kierkegaardian identity theory and these aspects of identity politics to be compatible in sustainable ways. In particular, Collins and Crenshaw both operate within a decidedly democratic set of social assumptions. Kierkegaard's relation to democracy is quite complicated, and so attributing democratic sensibilities to a Kierkegaardian identity theory should be done only with some 
reservations. Living in a monarchy all of his life, until the 1848 revolutions, the traditional individualist readings of Kierkegaard make it seem like his politics could be summarized by referring to his "sympathy for monarchy and his distaste for the revolutionary fervor of 1848" (Westphal 1991, p. 30). However, in light of the problems with such interpretations of his work, Merold Westphal suggests that Kierkegaard's politics cannot be reduced to such a caricature. Similarly, Bruce Kirmmse explains the tension at play in Kierkegaard's life that eventually leads him to be much more amenable to democracy than it might otherwise seem:

Kierkegaard, who in personal makeup and in many private matters, tastes, and preferences, was indeed a conservative aristocrat, in the end came not only to resign himself to the age of the common man, but positively to welcome it as the only alternative-risk filled though it was-to the spiritual suffocation which the continuation of urban elitist Christian culture seemed to guarantee.

(Kirmmse 1990, p. 5)

Kierkegaard had no interest in the "leveling" effects of popular sovereignty such that "vox populi" becomes confused for "vox dei". Additionally, his generally existentialist opposition to the herd/they/crowd, etc., would be out of place with a simple conception of democracy as majoritarian rule. Despite these hesitancies, though, Kierkegaard expressed long solidarity with the "common man" (Bukdahl 2001), and appreciated the way that a broadly democratic orientation kept open the possibility of constant transformation within social life.

Just as becoming a self is a task for a lifetime, democracy, as an idea of constant openness to the critique of the status quo from all members of society, can be productively read as the task of becoming as applied to justice. In this way, despite many reasons to be very careful about the parallel, Kierkegaard's mature view is roughly akin to the Derridean conception of democracy as always yet to come. Democracy is open-ended in ways that help to foster what Stephen Backhouse describes as the essential open-endedness of Kierkegaardian neighborly community (see Backhouse 2011). Democracy, thus, facilitates a disruption of the stagnation that can come with unquestionable monarchical authority. Or at least so Kierkegaard seemed to hope toward the end of his life. The risks remain, however, that the "People's Church" (as the state church was renamed after the revolutions of 1848) will just become a new form of the "Establishment" that equates the "perfections of eternity" with nothing more than one's own social instantiation of self-love. Fear and trembling should not only characterize the life of faith, but also the functioning of democracy.

Crenshaw, Collins, and Kierkegaard all offer "democratic" visions for a society that continue to unfold as penultimate and, thus, encourage constantly striving for a world in which we are all invested in being for others. Yet, when identity politics becomes a matter of narrowly circumscribing the range of views on offer for individuals such that neighbors become not much more than a voting-bloc, which sadly it can often do within a world guided by quantitative power, then both democracy and also community are undermined in ways that I think would give all three thinkers pause. We must be careful, then, on two fronts. First, we must distinguish between "identity politics" in the sense of appropriately understanding the "dissimilarities of earthly life" as the context in which neighbor-love occurs as a lived reality as guided by the equality made possible by recognizing all others as single-individuals before God, and "identity politics" as just another name for a particular social vision that operates according to the quantitative logic of the crowd.

Second, we must be wary of allowing "democracy" to become stabilized as a reinforcement of a populist status quo, but instead always maintain the "democratic" vision of what remains possible for human equality if love were truly enacted as a social reality. Admittedly, Kierkegaard does not think the latter is coherent without God. However, just invoking the name of God in political life does not accomplish much. Indeed, we should remember that what one might profess as "neighbor-love" always risks becoming corrupted into a "Christian" congregation/alliance-as sadly is happening all too frequently, especially in the U.S., within contemporary "Christian" nationalist movements-that serves 
to ignore the neighbor and operate out of self-protective fear. Kierkegaard works hard to ensure that "Christianity" is aware of the influence that populism would threaten to have upon it. In the 1855 postscript to the two notes of which the essay, "The Individual", consists, Kierkegaard explicitly warns against a facile reading of his work as simply directed toward increasing the quantitative crowd of those who identify as "Christians": "It is not my task, and in Christendom it cannot rightly be the task, to create a lot of titular Christians or to assist in confirming the millions in the illusion that they are Christian" (Kierkegaard 1962, pp. 127-38). Temptations to distort Christianity by accommodating it to the crowd are always present, but in a time when global populism is on the rise, they are increasingly prominent. Ultimately, Crenshaw's and Collins's secular defenses of the importance of singularity and individual dignity within embodied histories help us all remain vigilant regarding such temptations.

\section{Conclusions}

In conclusion, I want to stress that the Kierkegaardian account I have presented here is dangerously speculative if not supplemented by work that more explicitly realizes the relation of one's religious status as a single individual and the structural realities that form the context in which one's individual existence is lived out in finitude. We must position Kierkegaard at the very intersections that his own work so adeptly acknowledges and yet often fails to embrace explicitly enough. Kierkegaard's notion of the single individual is not detached from embodied historical realities, but also is not defined by them. As exemplified in the case study of the Samaritan woman, Kierkegaardian identity theory understands that we exist in lived social contexts, but those contexts are not exhaustively determinate of who we are. By appreciating this fact, and then seeking to live up to what it requires of us, we are better able to live as intersectionally located neighbors in community, rather than as anonymous competitors in the crowd, or as members of particular alliances defined by inappropriate self-love.

I have suggested that in Kierkegaard's account of the single individual there is nested a general identity theory that can and should be read as resonating with some aspects of contemporary standpoint and intersectionality theory. Caution is warranted though. We must remain aware that Kierkegaard's work, on its own, is insufficient to lead us to an eradication of all historical injustice and, as the identity blindness and alliance as self-love objections highlighted, his authorship remains a complicated source for the ends to which I am attempting to put it here. Nonetheless, appreciating the Kierkegaardian way that viewing ourselves and others as single individuals is the condition for true equality and neighbor-love helps to facilitate a better understanding of why working against injustice matters in the first place. So, whether or not Kierkegaard would have been willing to partner with Crenshaw and Collins in such work, I think that we Kierkegaardians should be.

Funding: This research received no external funding.

Acknowledgments: I would like to thank Merinda Simmons and Amber Bowen for some helpful suggestions for how to approach particular ideas in this essay. Also, I am indebted to Bryan Bibb for offering some resources for the section on John 4.

Conflicts of Interest: The author declares no conflict of interest.

\section{Notes}

1 In the next section, I will consider some of these Kierkegaardian passages and to the scholarship that attempts to read Kierkegaard as more relevant to political life than such passages would initially seem to suggest.

2 For more on Adorno's reading of Kierkegaard on this front, see Brittain (2017), Damgard (2020). Elsewhere I have responded at some length to Blanshard, see (Simmons 2011, pp. 37-52).

3 For detailed attempts to apply Kierkegaard to issues in political life, see the essays in Part Four of Simmons and Wood (2008).

$4 \quad$ Martín (2017) offers a general survey of this concept in Kierkegaard's thought. 
5 Evans goes on to suggest that Kierkegaard can be read as offering a "religious form" of virtue ethics (Evans 2019, p. 92). Interestingly, Sylvia Walsh rejects readings of Kierkegaard that stress his relation to virtue theory, and instead contends that he provides what is more appropriately understood as a "character ethics" (Walsh 2018, chap. 3).

6 I think this trend is especially prominent with those thinkers who attempt to secularize, or de-Lutheranize Kierkegaard's work in order to try to turn him into the progressive political thinker that we might wish he had been. As just one example of work that I think slides in this direction, see Dooley (2001). As an excellent response to this trend, especially as facilitated by a specifically Derridean reading of Kierkegaard, see Boesel (2021).

$7 \quad$ For an excellent account of Kierkegaardian epistemology and the role that lived perspective plays in it, see Piety (2010).

8 In a famously opaque passage in The Sickness Unto Death, Kierkegaard (under the name Anti-Climacus) offers the most explicit definition of a human being as a "spirit": "A human being is a spirit. But what is spirit? Spirit is the self. But what is the self? The self is a relation that relates itself to itself or is the relation's relating itself to itself in the relation; the self is not the relation but is the relation's relating itself to itself" (Kierkegaard 1980, p. 13). For more on Kierkegaard's notion of spirit, see Glenn (1987); Hannah (1987). For a suggestion of how such a conception of selfhood relates to various notions of community, see Crites (1992).

9 For a thorough recounting of the lived political context in which Kierkegaard's religious thought developed, see Barnett (2011); Backhouse (2011).

10 Here, Kierkegaard is drawing on John 14:6.

11 In an interesting description, Kierkegaard highlights the role that listening (and related concepts such as silence and communication) play in his work when he claims that this confusion amounts to "an acoustic illusion", which he names "pantheism" (Kierkegaard 1962, p. 135).

12 Here, it would be better to say "every person, absolutely every person" since Kierkegaard is clear in the Communion discourses that the gendered power structures that operate in the world have no bearing on God's relation to the individual (see, e.g., Kierkegaard 1997a, 1997b).

13 John Lippitt (2017) argues that along with gratitude, humility is one of the key Kierkegaardian virtues.

14 It is in respect to this dimension in Kierkegaard that Derrida (2008) rightly acknowledges that "tout autre est tout autre".

15 It is not unimportant that Kierkegaard spent much of his own life devoted to the plight of the "common man" in his society. See Kirmmse (1996), and especially Bukdahl (2001).

16 I say "arguably" because I have suggested elsewhere that texts such as Fear and Trembling and Practice in Christianity should be interpreted with an eye toward such social concerns as well. See, (Simmons 2007, 2021).

17 Kierkegaard never offers an extended consideration of the story in John 4 (though he does fairly frequently refer to John 4:24), but he does address Samaritans in other places, primarily in reference to the "Good Samaritan". See, for example, Kierkegaard (Kierkegaard 1995, pp. 22, 317, 323, 472; Kierkegaard 1990a, pp. 197-99; Kierkegaard 1990b, pp. 40-42). For engagements with Kierkegaard's retelling of the Good Samaritan, see Surman (2013); Pyper (2014); Damgard (2020); Ferreira (2001, pp. 31-36). For a substantive account of the history of the Samaritans, see Knoppers (2013).

19 Importantly, the view I will be defending here is not meant to contribute directly to the literature on the politics of difference, specifically, but more the literature that emerges in light of continental considerations of what living "after difference" might involve such that the pull of the other person is always embodied and located in socio-historical contexts, and yet their moral dignity is never reducible to such historical categories. In this way, I am attempting to think in parallel with work by Stephen Minister (2012) or Simon Critchley (2007) that develops such discussions in conversation with such thinkers as Chantal Mouffe and Emmanuel Levinas. That said, since I have offered extended considerations of Kierkegaard and Levinas elsewhere, such work will simply operate in the background for this much narrower essay (see Simmons and Wood 2008; Simmons 2011).

20 For more on the ways that Collins has recently developed intersectional theory as a critical social resource, see Collins (2019). See also Collins and Bilge (2020).

\section{References}

Adorno, Theodor. 1939. On Kierkegaard's Doctrine of Love. Studies in Philosophy and Social Science 8: 413-29. [CrossRef]

Adorno, Theodor. 1989. Kierkegaard: Construction of the Aesthetic. Translated by R. Hullot-Kentnor. Minneapolis: University of Minnesota Press.

Backhouse, Stephen. 2011. Kierkegaard's Critique of Christian Nationalism. Oxford: Oxford University Press.

Barnett, Christopher B. 2011. Kierkegaard, Pietism and Holiness. Farnham: Ashgate.

Blanshard, Brand. 1969. Kierkegaard on Faith. In Essays on Kierkegaard. Edited by Jerry H. Gill. Minneapolis: Burgess Publishing, pp. 113-26.

Blanshard, Brand. 1975. Reason and Belief. New Haven: Yale University Press.

Boesel, Chris. 2021. Kierkegaard's Garden with the Poppy Blooms: Why Derrida Doesn't Read Kierkegaard When He Reads Kierkegaard. Lanham: Lexington Books.

Brittain, Christopher Craig. 2017. Love as Power and Powerlessness: Kierkegaard and Adorno Revisited. Toronto Journal of Theology 33: 1-20. [CrossRef] 
Bukdahl, Jørgen. 2001. Søren Kierkegaard and the Common Man. Translated and Edited by Bruce H. Kirmmse. Grand Rapids: William B. Eerdmans.

Collins, Patricia Hill, and Sirma Bilge. 2020. Intersectionality, 2nd ed. Cambridge: Polity.

Collins, Patricia Hill. 2000. Black Feminist Thought. New York and London: Routledge.

Connell, George B., and C. Stephen Evans, eds. 1992. Kierkegaard's Vision of Community: Religion, Ethics, and Politics in Kierkegaard. New Jersey and London: Humanities Press.

Collins, Patricia Hill. 2019. Intersectionality as Critical Social Theory. Durham: Duke University Press.

Crenshaw, Kimberlé, ed. 2021. \#SayHerName: Black Women's Stories of State Violence and Public Silence. Chicago: Haymarket Books.

Crenshaw, Kimberlé. 1991. Mapping the Margins: Intersectionality, Identity Politics, and Violence Against Women of Color. Stanford Law Review 43: 1241-99. [CrossRef]

Critchley, Simon. 2007. Infinitely Demanding: Ethics of Commitment, Politics of Resistance. London: Verso.

Crites, Stephen. 1992. The Sickness Unto Death: A Social Interpretation. In Foundations of Kierkegaard's Vision of Community: Religion, Ethics, and Politics in Kierkegaard. Edited by George B. Connell and C. Stephen Evans. New Jersey and London: Humanities Press, pp. 144-60.

Damgard, Iben. 2020. Does Kierkegaard's Rewritten Parable of the Good Samaritan Leave the World to the Devil? Kierkegaard and Adorno on What it Means to Love One's Neighbor in the Modern World. Kierkegaard Studies Yearbook 25: 221-40. [CrossRef]

Derrida, Jacques. 2008. The Gift of Death, 2nd Edition and Literature in Secret. Translated by David Wills. Chicago and London: The University of Chicago Press.

Dooley, Mark. 2001. The Politics of Exodus: Kierkegaard's Ethics of Responsibility. New York: Fordham University Press.

Evans, C. Stephen. 2019. Kierkegaard and Spirituality: Accountability as the Meaning of Human Existence. Grand Rapids: William B. Eerdmans.

Ferreira, M. Jamie. 2001. Love's Grateful Striving: A Commentary on Kierkegaard's Works of Love. Oxford: Oxford University Press.

Garff, Joakim. 2005. Søren Kierkegaard: A Biography. Translated by Bruce Kirmmse. Princeton: Princeton University Press.

Glenn, John D., Jr. 1987. The Definition of the Self and the Structure of Kierkegaard's Work. In International Kierkegaard Commentary: The Sickness Unto Death. Edited by Robert L. Perkins. Macon: Mercer University Press, pp. 5-21.

Hannah, Alastair. 1987. Spirit and the Idea of the Self as a Reflexive Relation. In International Kierkegaard Commentary: The Sickness Unto Death. Edited by Robert L. Perkins. Macon: Mercer University Press, pp. 23-38.

Kierkegaard, Søren. 1962. The Point of View for My Work as an Author: A Report to History and Related Writings. Translated by Walter Lowrie. Edited by Benjamin Nelson. New York: Harper Torchbooks.

Kierkegaard, Søren. 1967. Søren Kierkegaard's Journals and Papers. Translated and Edited by Howard V. Hong, and Edna H. Hong. Bloomington: Indiana University Press.

Kierkegaard, Søren. 1980. The Sickness Unto Death: A Christian Psychological Exposition for Upbuilding and Awakening. Translated and Edited by Howard V. Hong, and Edna H. Hong. Princeton: Princeton University Press.

Kierkegaard, Søren. 1990a. Eighteen Upbuilding Discourses. Translated and Edited by Howard V. Hong, and Edna H. Hong. Princeton: Princeton University Press.

Kierkegaard, Søren. 1990b. For Self-Examination/Judge for Yourself! Translated and Edited by Howard V. Hong, and Edna H. Hong. Princeton: Princeton University Press.

Kierkegaard, Søren. 1992. Concluding Unscientific Postscript to Philosophical Fragments Vol. 1. Translated and Edited by Howard V. Hong, and Edna H. Hong. Princeton: Princeton University Press.

Kierkegaard, Søren. 1995. Works of Love. Translated and Edited by Howard V. Hong, and Edna H. Hong. Princeton: Princeton University Press.

Kierkegaard, Søren. 1997a. Christian Discourses/The Crisis and A Crisis in the Life of an Actress. Translated and Edited by Howard V. Hong, and Edna H. Hong. Princeton: Princeton University Press.

Kierkegaard, Søren. 1997b. Without Authority. Translated and Edited by Howard V. Hong, and Edna H. Hong. Princeton: Princeton University Press.

Kirmmse, Bruce H. 1990. Kierkegaard in Golden-Age Denmark. Bloomington: Indiana University Press.

Kirmmse, Bruce H., ed. 1996. Encounters with Kierkegaard: A Life as Seen by His Contemporaries. Bruce H. Kirmmse, and Virginia R. Laursen, transs. Princeton: Princeton University Press.

Knoppers, Gary N. 2013. Jews and Samaritans: The Origins and History of their Early Relations. Oxford: Oxford University Press.

Lippitt, John. 2017. Kierkegaard's Virtues? Humility and Gratitude as the Grounds of Contentment, Patience, and Hope in Kierkegaard's Moral Psychology. In Kierkegaard's God and the Good Life. Edited by Stephen Minister, J. Aaron Simmons and Michael Strawser. Bloomington and Indianapolis: Indiana University Press, pp. 95-113.

Mackey, Louis. 1962. The Loss of the World in Kierkegaard's Ethics. The Review of Metaphysics 15: 602-20.

Martín, José García. 2017. The Category of the Single Individual in Kierkegaard. European Journal of Science and Theology 13: 99-108.

Minister, Stephen. 2012. De-Facing the Other: Reason, Ethics, and Politics After Difference. Milwaukee: Marquette University Press.

Nussbaum, Martha C. 1999. Sex and Social Justice. New York and Oxford: Oxford University Press.

Pattison, George. 2005. The Philosophy of Kierkegaard. Montreal: McGill-Queen's University Press.

Piety, M. G. 2010. Ways of Knowing: Kierkegaard's Pluralist Epistemology. Waco: Baylor University Press. 
Pyper, Hugh. 2014. What's So Good About the Good Samaritan? Kierkegaard and Løgstrup on the Neighbor. Presentation for Study Day on Kierkegaard to Løgstrup: The Danish Interest in Personal Responsibility. Sheffield: University of Sheffield, (April 4). Currently Unpublished.

Simmons, J. Aaron. 2007. "What About Isaac: Re-Reading Fear and Trembling and Re-Thinking Kierkegaardian Ethics. Journal of Religious Ethics 35: 319-45. [CrossRef]

Simmons, J. Aaron. 2011. God and the Other: Ethics and Politics After the Theological Turn. Bloomington and Indianapolis: Indiana University Press.

Simmons, J. Aaron. 2021. Militant Liturgies: Practicing Christianity with Kierkegaard, Bonhoeffer, and Weil. Religions 12: 340. [CrossRef]

Simmons, J. Aaron, and David Wood. 2008. Kierkegaard and Levinas: Ethics, Politics, and Religion. Bloomington and Indianapolis: Indiana University Press.

Surman, Darren. 2013. Love, The Singular Existence, and the Limits of Philosophy. Rivista di Filosofia Neo-Scolastica 105: 633-44.

Tilley, Michael. 2013. Kierkegaard and Recent Continental Philosophy of Religion. Philosophy Compass 8: 400-8. [CrossRef]

Walsh, Sylvia. 1999. Other-Worldliness in Kierkegaard's Works of Love-A Response. Philosophical Investigations 22: 80-85. [CrossRef]

Walsh, Sylvia. 2018. Kierkegaard and Religion: Personality, Character, and Virtue. Cambridge: Cambridge University Press.

Westphal, Merold. 1991. Kierkegaard's Critique of Reason and Society. University Park: The Pennsylvania State University Press.

Westphal, Merold. 2013. Society, Politics, and Modernity. In The Oxford Handbook to Kierkegaard. Edited by John Lippitt and George Pattison. Oxford: Oxford University Press, pp. 309-27.

Young, Iris Marion. 1990. Justice and the Politics of Difference. Princeton: Princeton University Press. 